\title{
山地部蛇行河川の洪水流に及ぼす 地形形状の影響について THE EFFECT OF CONFIGURATION ON FLOOD FLOW IN STREAM VALLEY
}

\author{
服部和彦 1 ・石垣泰輔 2 ・上野鉄男 3 \\ Kazuhiko HATTORI, Taisuke ISHIGAKI and Tetsuo UENO \\ 1学生員 関西大学大学院生 工学研究科（干 564-8680 吹田市山手町3丁目3番35号) \\ 2正会員 工博 関西大学教授 環境都市工学部 都市システム工学科 \\ (干564-8680 吹田市山手町3丁目3番35号) \\ 3正会員 工博 元京都大学助手 防災研究所（干611-0011 宇治市五ヶ庄）
}

\begin{abstract}
The flood disaster in a stream valley is discussed with experimental results by water surface flow visualization and water level measurement. From a field survey, it is found that the magnitude of damage is dependent on valley width, which implies the change of flood flow depth on the alluvial plain, and river width at the bend apex. As experimental results, the magnitudes of water surface velocity and divergence around the apex are large for deep condition on the flood plain and narrow channel width at the bend apex, implying that significant erosion can occur around a bend. Thus it is important to understand the effect of configuration on flood flows and appropriate river width at the bend apex to reduce flood damages in a stream valley.
\end{abstract}

Key Words : flood disaster, stream valley, compound meandering channel flow, water surface velocity, divergence

\section{1. はじめに}

近年，集中豪雨の増加により各地で激甚な水害が発 生している. 特に, 時間雨量 $50 \mathrm{~mm}$ を超える短時間で集中 した豪雨の発生回数が増加した. 山地部は都市部と異な り, 蛇行河川が多く存在し, 湾曲頂部内岸に形成された 新たな土地では，河道幅を狭くするような土地利用がな されている，一方，これら河道周辺の水害に対する河川 整備は進んでいない，このようなことから，河道の流下 能力をはるかに超える未曾有の豪雨が山地部を襲うと激 甚な水害が発生する. 山地部における洪水は, 谷幅が狭 いために洪水流は谷底平地全体を流れ，大量の土砂を含 んだ流れは流域に深刻な被害をもたらす。近年報告され ている山地部における水害として，1998年の余笹川水害， 2004年の福井豪雨による足羽川山地流域における水害な どが挙げられる. 本研究では, 足羽川水害を対象とし, 山地部蛇行河川における水害について検討を行った.

足羽川水害に関しては，これまでに多くの調查が行わ れている. 例えば，足羽川中流部における調査として， 服部・山本 ${ }^{1)}$ は浸食・運搬・堆積作用に焦点をあて調査
を行っている，また上野・石坦 ${ }^{2}$ は, 谷底平野の形態・ 平地の土地利用などに焦点をあて調査を行っている.

本研究では, 既報2)で問題提起された流水幅の違いに よって被害状況が異なること, 湾曲頂部の河道幅が狭い 地域または河道幅は広いが河道内に大量の土砂が堆積し て流水幅が狭くなった地域で被害が大きかったこと，ま た, 河道幅が広く保たれて流水幅が確保されている地域 では被害が小さかったという指摘に着目した。このよう に湾曲頂部の流水幅が被害の大小を決定する1つの要因 であることが報告されている，また，調查報告と航空写 真を用いて各地域の土砂の被り具合を比較寸ることで, 谷幅の違いによって被害が異なることが確認されている. 写真-1は, 横越町周辺の被害状況である. 上流の (A) 地 区と下流の (B) 地区で被害状況が異なる。これは，谷幅 が違うことから, 谷底平地を流れる洪水流の水深が変化 したことに起因する. 谷幅が狭い地域では, 洪水流の水 深は高くなり谷幅全体に土砂が堆積し被害が大きい。一 方で，谷幅が広い地域では，水深は低くなり河道湾曲部 入り口から湾曲頂部にかけて土砂が広がり局所的に被害 が大きい. このように, 谷幅の違いが谷底平地を流れる 洪水流の水深に変化をもたらし, 被害状況が異なるとい 

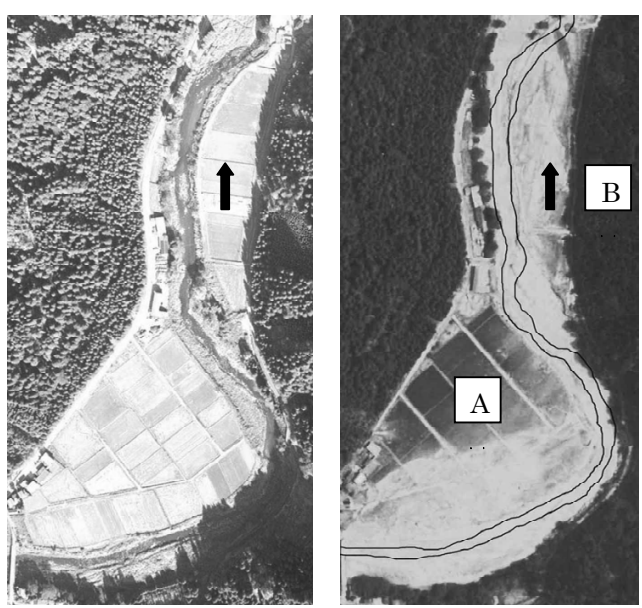

写真-1 足羽川中流域横越町周辺の災害前後の 航空写真(左) 災害前 (右) 災害後
表-1 水理条件

\begin{tabular}{ccc} 
Dr & $\mathrm{Q}(\mathrm{m} 3 / \mathrm{s})$ & $\mathrm{H}(\mathrm{m})$ \\
\hline \hline Bankfull & 0.001335 & 0.0360 \\
Dr $=0.17$ & 0.001140 & 0.0434 \\
Dr=0.31 & 0.002347 & 0.0522 \\
Dr $=0.45$ & 0.005986 & 0.0655 \\
\hline
\end{tabular}

\begin{tabular}{ccc}
$\mathrm{U}(\mathrm{m} / \mathrm{s})$ & $\mathrm{Fr}$ & $\mathrm{Re}$ \\
\hline \hline 0.185 & 0.36 & 4900 \\
0.087 & 0.23 & 1300 \\
0.116 & 0.25 & 2600 \\
0.194 & 0.34 & 6400 \\
\hline
\end{tabular}

Dr : 相対水深, Q : 流量, $H$ : 水深, $U$ : 平均流速,

Fr : フルード数 Fr $=\mathrm{U} /(\mathrm{gR})^{1 / 2}, \operatorname{Re}:$ レイノルズ数 $\mathrm{Re}=\mathrm{UR} / v$

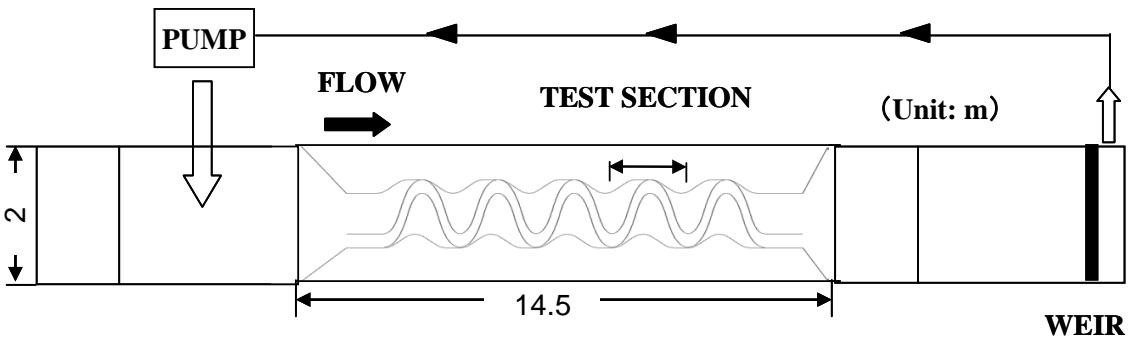

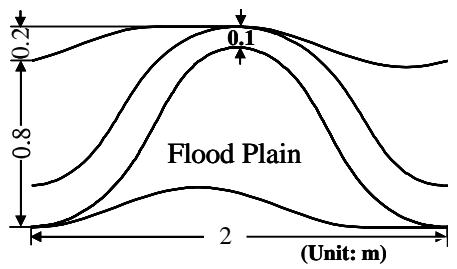

(a) 水路幅漸縮

図-1 実験水路

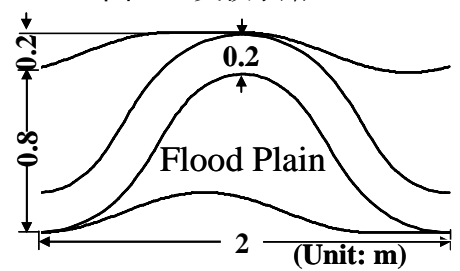

（b）水路幅一様

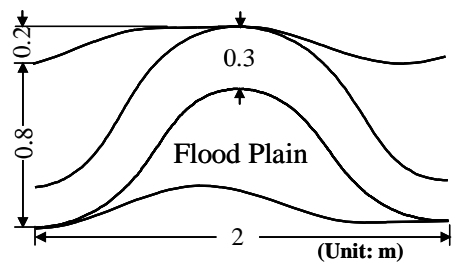

(c) 水路幅漸拡

図-2 測定部

う指摘にも着目した。

山地部蛇行河川の両側には谷幅が狭い谷底平野が連続 的に存在することにより，洪水流は谷幅全体を流下する. このため, 山地部における洪水流は複断面蛇行流と類似 した流れと考えることができる．複断面蛇行流について は，水路幅一様かつ高水敷堤防が直線である水路を用い て多くの研究 ${ }^{3) 4}$ が行われている. 一方で，福岡ら51 より実在の河川を想定し低水路と高水敷上堤防がともに 蛇行し, 両者の間に位相差をもつ水路を用いて実験を 行っている.しかし, 福岡ら ${ }^{5)}$ の実験水路が山地河川の 河道特性を反映しているかは疑問である。実際には山地 部河川の河道幅は一様ではなく，谷幅は狭く低水路と谷 境界は異なる位相で蛇行している.

本研究は，地形変化が流れにどのような影響を与える かを検討することを目的とし，地形変化の影響による流 れの変化と被害状況とを比較検討することによって水害 を軽減させるための見解を得ようとするものであり，以 下に示す基礎的な実験を行った.

\section{2. 実験概要}

図-1に実験水路を示す，足羽川・余笹川を対象とした 各地域の河道特性の調査結果より平均蛇行度1.35, 平均 最大偏角約 $50^{\circ}$ ということが確認された。 また, Yalin ${ }^{6)}$ は理想的な河川形状としてsine-generated curveを挙げ ている. 以上を考慮した上で，山地部蛇行河川の地形変 化に着目した複断面蛇行水路を作成した。ただ，河床 勾配を考慮していないため, 山地河道の実相を反映して いない. 概略を以下に示す. 1波長 $2 \mathrm{~m}$ の蛇行部を5波長設

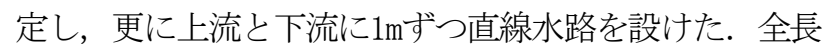
は14.5m，水路勾配は1/800である。低水路を最大偏角 $60^{\circ}$ となる sine-generated curveで描き, 蛇行度 $(=$ 流 路長/波長)を1.34とした。また，蛇行に伴う流路変動が 谷地形の影響で停止した状態を想定し，高水敷の蛇行は sine curveで描き，蛇行度を 1.03 とした。低水路幅は $0.2 \mathrm{~m}$ ，谷幅は $0.8 \mathrm{~m}$ であり，高水敷高さを $0.036 \mathrm{~m}$ とた. なお，図-2に上流から4波長目に設定した測定部を示す.

表-1に水理条件を示す，実験では，谷幅の違いにより 

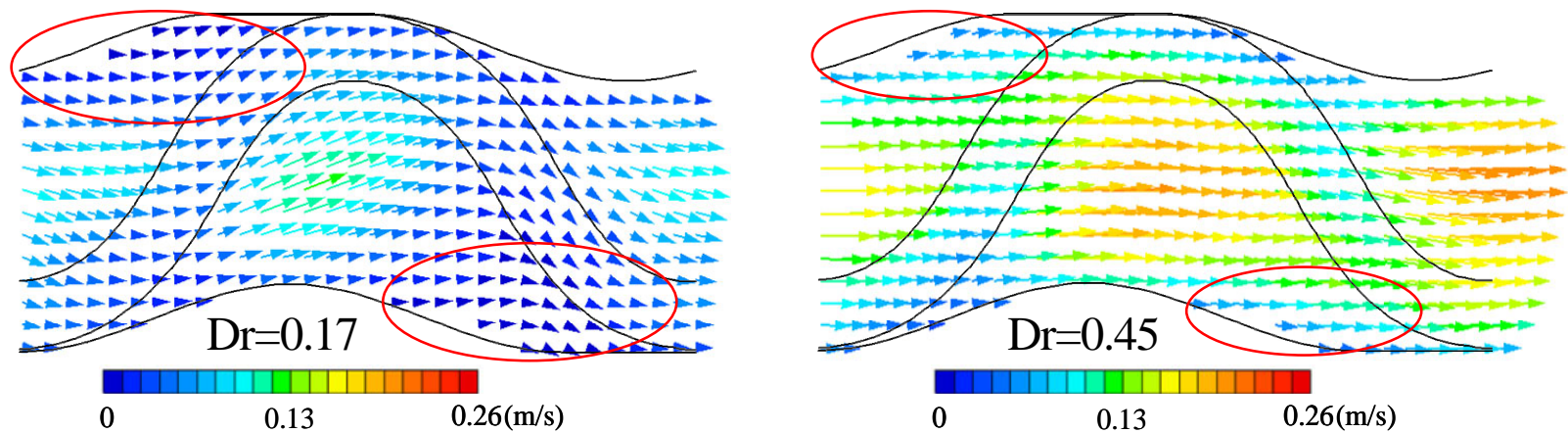

図-3 水路幅一様における表面流速分布図

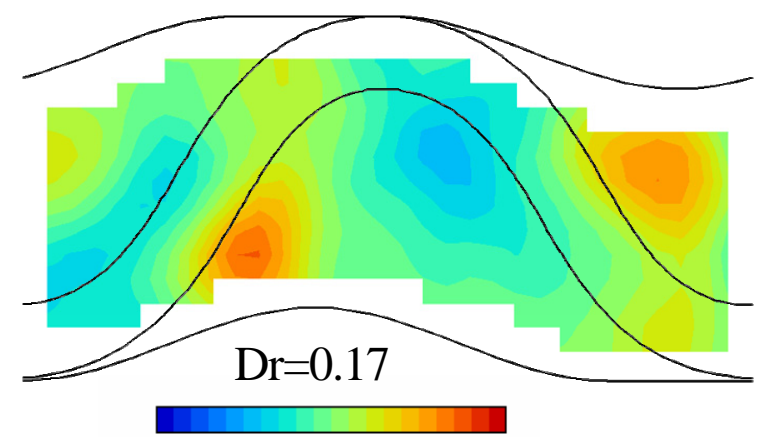

$-0.55$

0.55

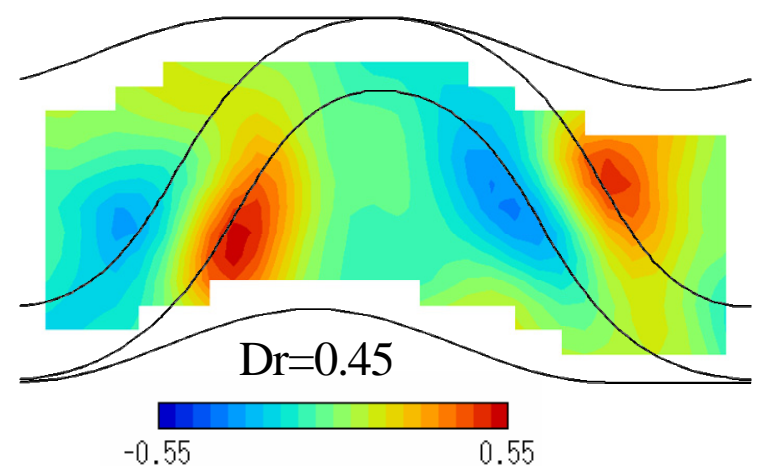

図-4 水路幅一様における発散分布図

平地を流れる水深が変化することに着目し，水路幅一様 において高水敷上水深を変化させた実験を行った. 高水 敷水深の変化の指標として相対水深 Dr $(=(H-h) / H, H$ : 低水路水深, $\mathrm{h}$ : 低水路深さ) を用いた. 既存の研究 $)^{2}$ に より Dr=0.25〜0.30において流れの構造が変化すること が報告されていることより，Bankful1（河道満杯状態）, 谷幅が広く平地を流れる水深が浅い時を想定した Dr=0.17，谷幅が狭く平地を流れる水深が深い時を想定 したDr=0.45, Dr=0.17と0.45の間で流れの構造が変化す ると予測されるDr=0.31の4ケースで実験を行った。 その 後, 低水路幅一様を基準として, 湾曲頂部の水路幅の変 化が流れにどのような影響を与えるかを検討するために, 図-2に示すように水路幅を漸縮または漸拡させて実験を 行った．湾曲頂部の水路幅はそれぞれ0.1m(水路幅漸縮), $0.3 \mathrm{~m}$ (水路幅漸拡) である.

乾燥状態で十分に水表面に浮遊する直径 $0.08 \mathrm{~mm}$, 比重 1.5の塩化ビニルのトレーサーを用い測定部上流から散 布し，測定部上方に設置したビデオカメラを用いて表面 流況を撮影した. 撮影された動画から1秒30フレームの 静止画を抽出し，インタレース解除，グレースケール化 を行った後にPIV解析法を用いて表面流速を求めた。ま た，水位は測定部の上流側高水敷を基準として超音波水 位計を用いて測定した．なお，測定を開始する前に上流 側と下流側の水深をポイントゲージにより測定し，等流 状態であることを確認した.

更に，山地部の被害状況を検討するため侵食作用を検 討したが，ここでは水路床近傍の流速が不明確なため掃 流力による十分な検討を行うことができなかった. その
ため, 発散を用いた定性的な検討を行った.

\section{3. 実験結果と考察}

\section{（1）相対水深の変化について}

図-3に水路幅一様における表面流速分布図を示す。図 より，高水敷の水深が増加するとともに流速は速くなり， 流れの向きが変化することがわかる. 既存の研究3) と同 様にDr=0.17では，高水敷の水深が浅いために低水路の 流れの影響を受けて湾曲部入り口から湾曲頂部に向かっ て蛇行するように流れる。一方で，Dr=0.45では，高水 敷の水深が深いために表面流速は低水路の流れの影響を 受けずに水路全体を流下方向に対し直進して流れる.

図-4に水路幅一様における発散分布図を示す。発散の 值は以下の式を用いて計算した。

$$
\operatorname{div}=\frac{\partial u}{\partial x}+\frac{\partial v}{\partial y}
$$

$u, v$ はそれぞれ流下方向，横断方向表面流速成分を表す. 水表面でのデータであることから，正の值は流体の湧出 しを表し，負の值は沈込みを表す，特に，低水路と高水 敷の境界部では，正の值は低水路から高水敷への上昇流， また負の值は高水敷から低水路への下降流を表す。その ため, 発散は侵食作用を考える上で1つの指標となる.

図-4より低水路と高水敷の境界部で発散の絶対值が大き いことがわかる. 特に, 湾曲頂部周辺で沈込みの絶対值 が大きく，強い下降流の影響により侵食作用が激しくな 

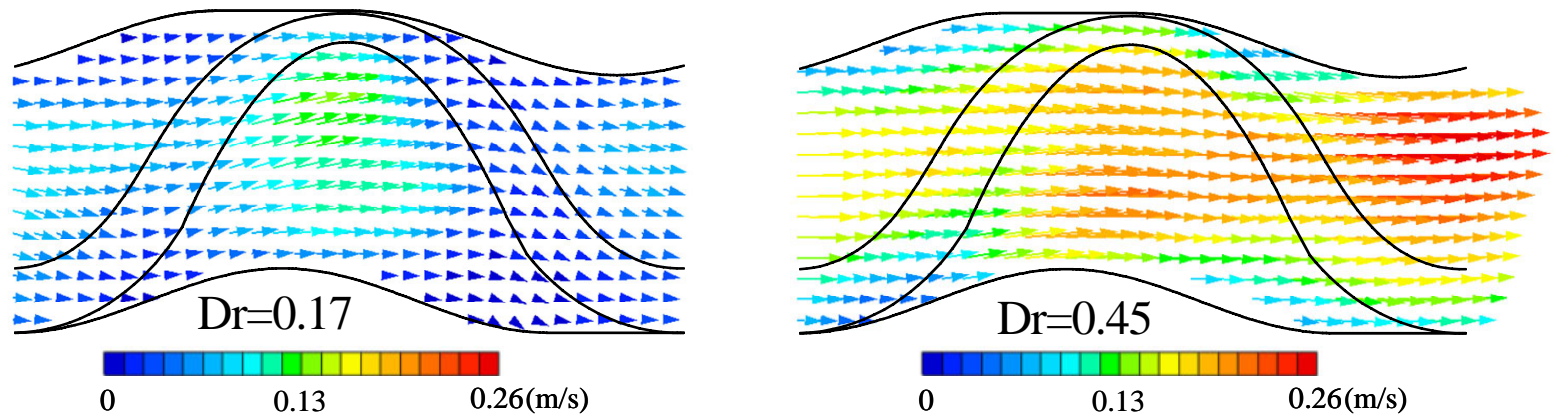

図-5 水路幅漸縮における表面流速分布図
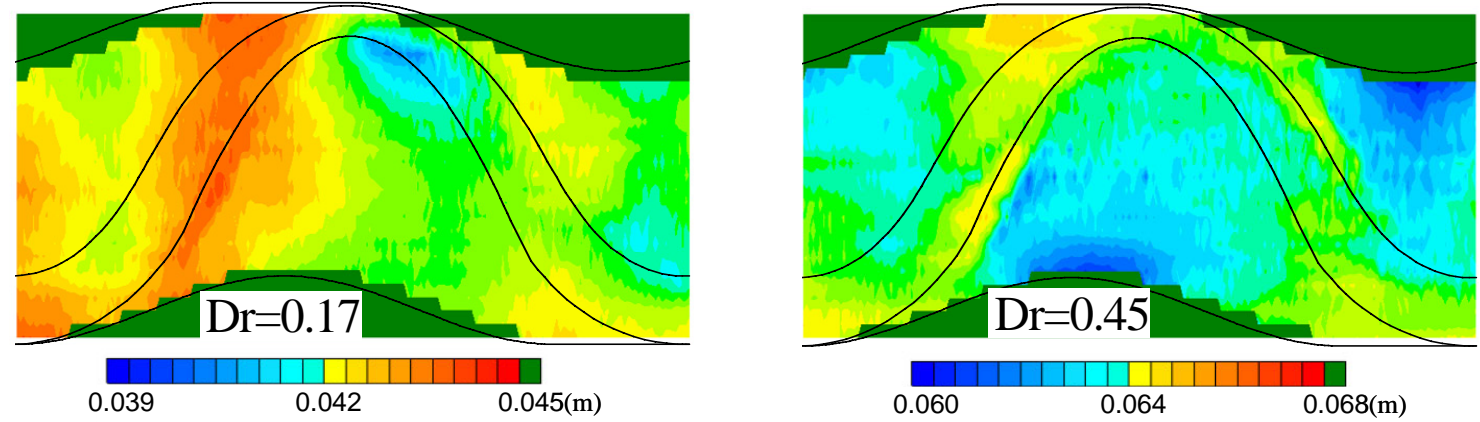

図-6 水路幅漸縮における水深分布図
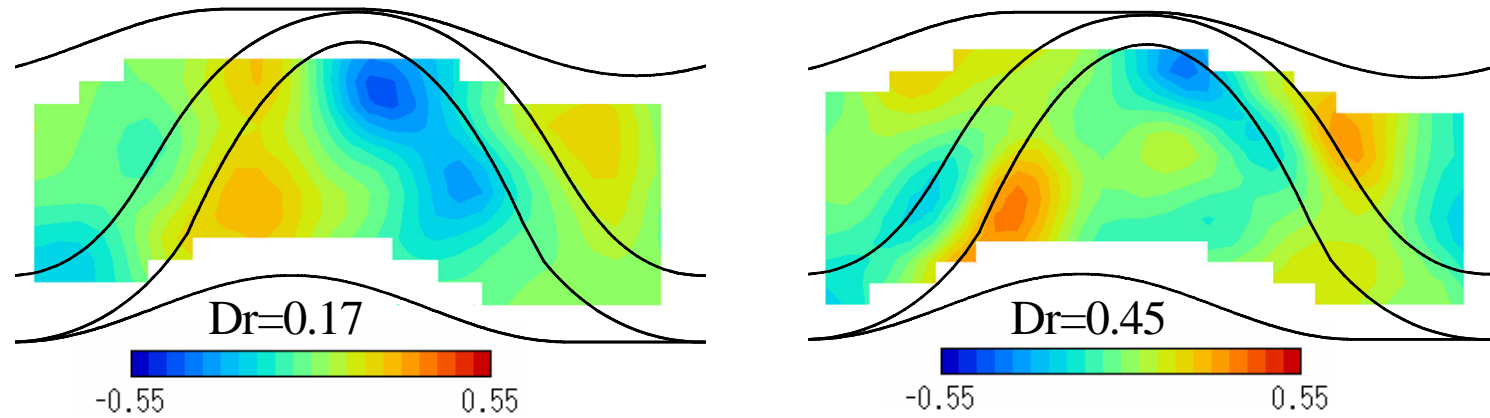

図-7 水路幅漸縮における発散分布図

ることを示唆する. なお，高水敷水深の増加に伴い発散 の絶対值が大きくなるため，侵食作用がより激しくなる ことが予測される。

また，谷の蛇行の影響が谷境界付近で見られる．図-3 の赤丸に示すように，谷の蛇行の影響により，谷の湾曲 頂部で谷の蛇行に沿った流れが剥離するため，その下流 側で周辺より表面流速が小さく水深が深くなる後流域の 存在が見られる。これは，福岡ら5) の研究における堤防 先行位相において, 高水敷流れが低水路向きの堤防法線 の影響を受け，その下流側が死水域に近い状況を示して いる事と類似している.

以上の結果と被害状況を比較すると, 谷幅の広い地域 で河道湾曲部入り口から湾曲頂部にかけて土砂が広がり 被害が局所的であったことは，高水敷の水深が浅いケー スにおいて表面流速と発散の絶対值が大きい箇所と表面 流速の流れの向きが等しいことと一致している. また， 谷幅が狭い地域で谷幅全体に土砂が被り被害が大きかっ たことは，高水敷の水深が高いケースにおいて谷幅全体 に流れが広がり，表面流速が大きく発散の絶対值が大き いことと一致している。これより，流れの構造から谷幅
の変化による被害状況を予測できる.

\section{（2）水路幅の変化について}

\section{a) 水路幅が漸縮する場合}

図-5，図-6に水路幅漸縮における表面流速分布図と水 深分布困を示す．水深分布図は低水路底面から測った水 深を表した図である.上流側の水深が高くなり右岸高水 敷上の表面流速が増加する。これは，低水路幅の漸縮に 伴って低水路内の流下能力が減少し, 湾曲頂部で流れが 堰き上がり上流側の流れの構造に影響を与えた結果，上 流側の水深が高くなり水面勾配が急となったためである. 表-2に右岸高水敷上の水面勾配を示す，水面勾配は各 ケースの表面流速分布図で右岸高水敷上の流速が最大で あるべクトルの向きに沿ってそれぞれ求めた。水路幅漸 縮と他の形状を比較すると，水路幅漸縮のケースで水面 勾配が最も急となるために高水敷上の表面流速は他の形 状と比べて速くなる.

図-7に水路幅漸縮における発散分布図を示す。水路幅 一様のケースと比較すると湾曲頂部付近で沈込みの絶対 值が大きく, 高水敷から低水路へ流れる下降流が強いこ 
表-2 右岸高水敷上の水面勾配

\begin{tabular}{|c|c|c|c|}
\hline & 水路幅漸縮 & 水路幅一様 & 水路幅漸拡 \\
\hline Bankfull & $1 / 157$ & - & - \\
\hline $\mathrm{Dr}=0.17$ & $1 / 169$ & $1 / 256$ & $1 / 483$ \\
\hline $\mathrm{Dr}=0.31$ & $1 / 294$ & $1 / 323$ & $1 / 769$ \\
\hline $\mathrm{Dr}=0.45$ & $1 / 556$ & $1 / 667$ & $-1 / 5556$ \\
\hline
\end{tabular}
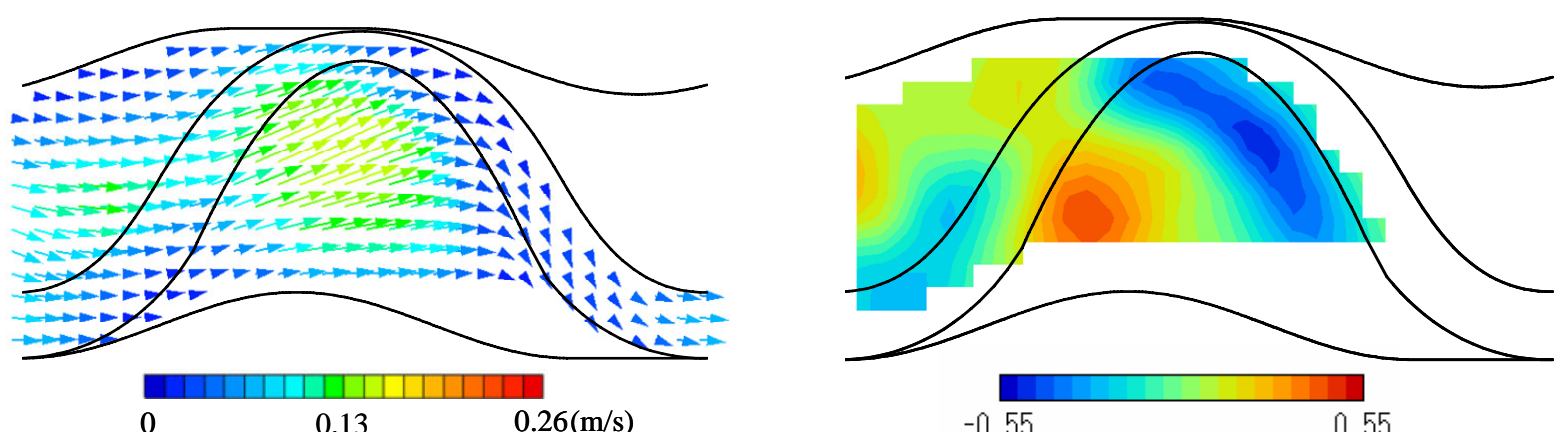

図-8 水路幅漸縮のBankful1における(左)表面流速分布図と(右)発散分布図
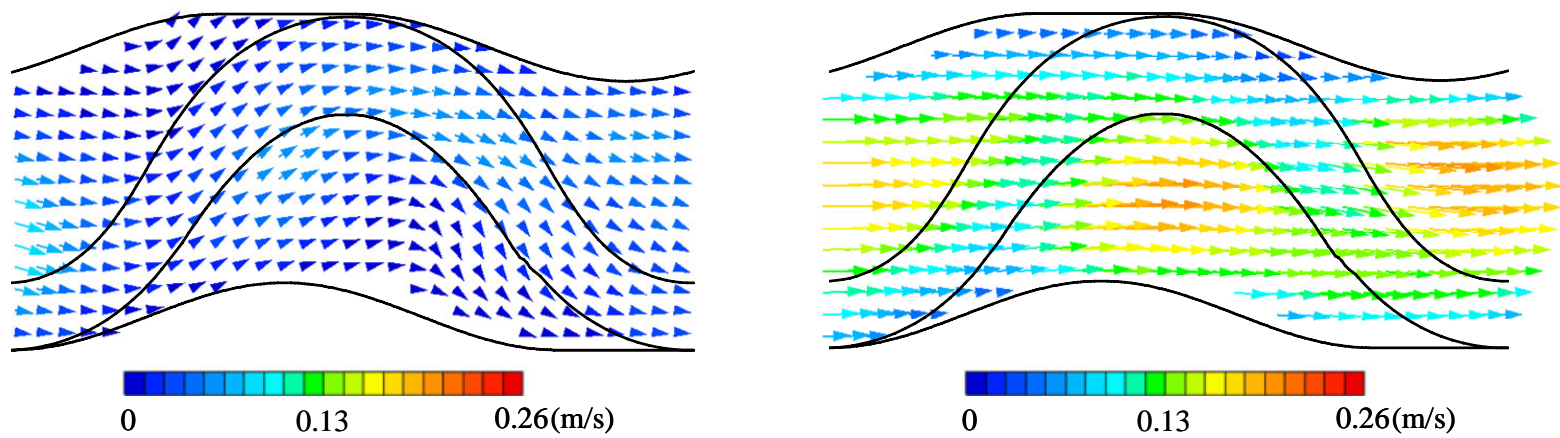

図-9＼cjkstart水路幅漸拡における表面流速図
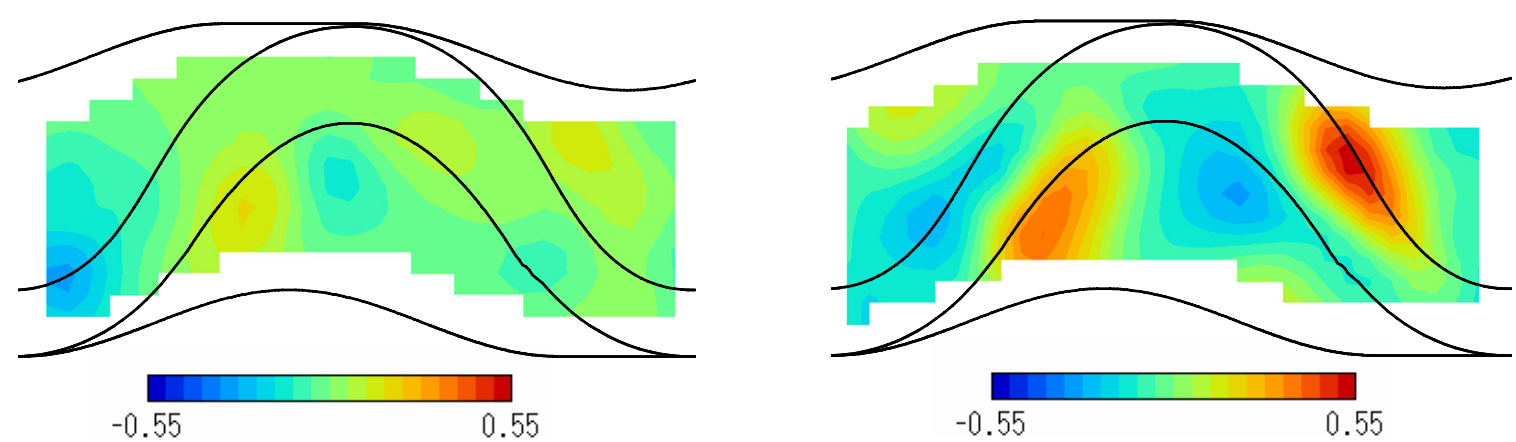

図-10＼cjkstart水路幅漸拡における発散分布図

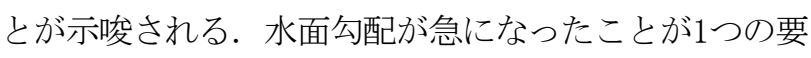
因であり, この結果湾曲頂部周辺における侵食作用が大 きいことが予測される.

特に注目する点としてBankful1のケースが挙げられる. 図-8にBankfullの表面流速分布図と発散分布図を示寸. 表面流速，沈込みの絶対值が $\mathrm{Dr}=0.17$ よりも大きい. 水 路幅が漸縮寸るために低水路内の流下能力が減少し上流 側で流れが高水敷へ乗り上げる. しかし，下流側では低 水路幅は一様時の広さに戻るために乗り上げは発生しな い. その結果，上流と下流の水深差が大きくなり，水面 勾配はDr $=0.17$ よりも急となり表面流速は速くなる.ま た，水面勾配が急となったことにより湾曲頂部付近の沈
込みの絶対值は大きくなり，その範囲は広く低水路への 下降流が下流側で激しくなることが予測される.

以上のことより，湾曲部頂部が狭いケースでは，水路 幅が漸縮し水路幅一様のケースと比較すると表面流速が 増加し, 湾曲頂部付近の沈込みが大きくなるため侵食作 用が激しくなることが予測される。これは，湾曲頂部の 流水幅が狭い地域で被害が大きくなることの要因である と考えられる. また, BankfullとDr=0.17の比較により 湾曲頂部が狭い地域では，越流が始まる洪水の初期段階 で被害が大きくなることが予測される.

b) 水路幅が漸拡する場合

図-9, 図-10に水路幅漸拡における表面流速分布図と 
発散分布図を示す. Dr=0.17において，表面流速は水路 幅一様のケースよりも小さく, 発散の絶対值も小さい. これは，水路幅の漸拡にともない低水路の流下能力が増 加し, より多くの流量が低水路内を流れるためである.

また, 下流側で水路幅が一様に戻るために低水路内に収 まらなかった流れが高水敷上一溢れ出寸ため下流側低水 路周辺で水深が高くなる. その結果, 右岸高水敷上の水 面勾配は緩やかになり表面流速は遅くなるとともに，湾 曲頂部付近での発散の絶対值は小さくなり水路幅一様の 時と比べて侵食作用が弱いことが予測される.

しかし，高水敷上の水深が大きくなるD $=0.45 て ゙ は ，$ $\mathrm{Dr}=0.17$ と同様の傾向は見られない. これは，低水路を 流れる流量よりも高水敷を流れる流量のほうが多いこと と，相対水深が大きくなると，全般に高水敷上の流れが 低水路内の流れよりも卓越する ${ }^{3}$ ことより低水路形状の 変化の影響をほとんど受けないためである.

以上のことより，水路幅が漸拡する湾曲頂部が広い ケースでは，水路幅が一様のケースと比べて谷底平地を 流れる水深が低い地域，つまり谷幅が広い地域で被害状 況が小さくなることが予測できる．一方で，谷幅が狭く 谷底平地を流れる洪水流の水深が高くなる地域では十分 に流水幅を確保しても，地形の変化が流れの構造に影響 を与えなくなり被害をより減少させることは難しいと考 えられる。

\section{4. 結論}

本研究では, 地形変化が流れの構造にどのような影響 を与えるかを検討した。 ここで得られた結果を列挙する と以下のようである.

\section{（1）谷幅の違い(平地を流れる水深の違い)}

高水敷の水深が低い時，低水路の流れの影響を受け表 面流速は蛇行して流下寸る. 一方で, 高水敷の水深が高 い時，流れは水路全体を直進しながら流下寸る．また， 高水敷水深の増加に伴い表面流速と発散の絶対值は増加 し，湾曲頂部付近で侵食作用が大きくなり被害が大きく なることが予測される.

（2）流水幅の違い

a) 流水幅が漸縮する場合

水路幅一様と比較し，水路幅漸縮では低水路の流下能 力が低下寸るため, 流れが湾曲頂部で堰き上がり上流側 の流れの構造に影響を与える. その結果, 右岸高水敷上 の水面勾配は急となり表面流速と沈込みの絶対值が増加 する. このため, 侵食作用は大きくなり水路幅一様と比 べて被害が大きくなることが予測される.

b）流水幅が漸拡する場合

水路幅一様と比較し, 水路幅漸拡では低水路の流下能
力が増加するために低水路内を流れる流量が増加し, 水 面勾配は緩やかとなる。 その結果, 表面流速は低下し, 発散の絶対值も小さくなる. このため, 侵食作用が弱ま り水路幅一様と比べ被害が小さくなることが予測される. しかし, 高水敷水深の上昇とともに, この傾向は弱まり 水路幅一様のケースと同様の流れに近づく．このことか ら, 流水幅を十分に確保しても高水敷水深が高くなるに つれて被害を減少させることは難しくなる.

以上のことより, 地形の変化が流れの構造に影響を与 えることが示された. 山地部において, 谷幅が狭く集落 が存在する地域，河道幅を狭くするような土地利用をし ている地域や河道幅が広くても河道内に大量の土砂が堆 積し流水幅が狭くなっている地域では, 被害が大きくな ることが予測される. そのため, 山地部の水害を軽減さ せるために, 谷幅が狭い地域では早期避難を行うことや, 山地部全域で流水幅が狭くならないような土地利用の在 り方を考え，河道幅を十分に確保できるように河道及び 河川周辺の整備を進めることが減災上考慮すべき事項の 1つであると言える.

本研究では，地形の変化が流れに与える影響に着目し， 基礎的な研究を行った．今後は, 地形変化による流れの 変化を数值解析を用いて検討寸ることや侵食・堆積を考 慮した移動床現象を検討することなどが必要である.

謝辞: 本研究を行うにあたり, 京都大学防災研究所宇 治川オープンラボラトリーより実験施設を提供して頂い た.ここに記し謝意を表す。

\section{参考文献}

1）服部 勇・山本 博文: 平成16年7月の福井豪雨の堆積学的 側面(足羽川中流部における浸食, 運般, 堆積作用), 福井市自 然史博物館研究報告 第52号, 1-11，2005.

2）上野 鉄男・石垣 泰輔 : 足羽川流域における2004年水害 について, 京都大学防災研究所年報第48号 B, pp. 657-671, 2005.

3）武藤 裕則・塩野 耕二 ・今本 博健 $\cdot$ 石垣 泰輔: 複断 面蛇行開水路流れの水理特性について(1), 京都大学防災研究 所年報 第38号 B-2, pp. 561-580, 1995.

4）福岡 捷二 - 大串 弘也 - 加村 大輔 - 平生 昭二 : 複断 面蛇行流路における洪水流の水理, 土木学会論文集No. 579/II41, pp. 83-92, 1997.

5）福岡 捷二・大串 弘也・岡部 博一: 複断面蛇行流れに 及ぼす堤防と低水路の蛇行度と位相差の影響, 水工学論文集第 42巻, pp. 961-966, 1998.

6) M. Selim YALIN : River Mechanics, PERGAMON PRESS, 1992. 7) 石垣 泰輔 - 武藤 裕則: 複断面蛇行開水路流孔の構造と 底面せん断分布について, 水工論文集第42巻, pp. 901-906, 1998.

(2007. 9. 30受付) 